ks. Stanisław Wronka

\title{
XI Ekumeniczne Dni Biblijne (2004)
}

W maju 2004 roku obchodziliśmy już po raz jedenasty Ekumeniczne Dni Biblijne ze Świętem Biblii 9 maja. Jest to inicjatywa Towarzystwa Biblijnego w Polsce, które pragnie w ten sposób przybliżyć Pismo Święte wiernym różnych wyznań, a przez to zbliżyć ich także do siebie. Ta forma apostolatu biblijnego i ekumenicznego zatacza coraz szersze kręgi i przynosi coraz bogatsze owoce.

Majowe świętowanie Biblii zostało przygotowane przez Komitet Krajowy Ekumenicznych Dni Biblijnych, który spotkał się 16 marca 2004 r. w domu Towarzystwa w Warszawie-Falenicy. Spotkanie otworzył ks. prał. Jerzy Banak, przewodniczący Komitetu, który pozdrowił wszystkich uczestników - przedstawicieli diecezji katolickich i reprezentantów wyznań protestanckich, zwłaszcza przybyłych po raz pierwszy, dziękując jednocześnie tym, którzy angażowali się w tę inicjatywę od lat, wśród nich szczególnie ks. prof. Jerzemu Chmielowi. Następnie ks. Banak przedstawił nową dyrektor Towarzystwa, p. Małgorzatę Platajs, wybraną przez wszystkie dziewięć kościołów należących do Towarzystwa. Zastąpiła ona 1 stycznia 2004 r. p. Barbarę Enholc-Narzyńską, która przygotowywała poprzednie spotkania. W swoim słowie nowa dyrektor podkreśliła wielką wagę Ekumenicznych Dni Biblijnych, gdyż inicjatywa ta angażuje nie tylko elity, ale dociera do całego ludu Bożego, uwrażliwiając go na Słowo Boże, które jest fundamentem życia chrześcijańskiego.

Następnie uczestnicy podzielili się doświadczeniami z ubiegłorocznych Dni Biblijnych. Nie zawsze odbywały się one w maju, ale w niektórych diecezjach i wspólnotach miały bardzo bogaty program. Składały się na niego: ekumeniczne nabożeństwa biblijne, wspólna lektura Pisma Świętego, sympozja i wykłady poświęcone Biblii, wystawy, prezentacje nowych środków audiowizualnych, konkursy czytania Biblii (np. dla lektorów) i z wiadomości o Biblii, koncerty inspirowane Biblią... Miejscem tych wydarzeń były nie tylko świątynie, lecz także sale uniwersyteckie, domy kultury i gmachy urzędów samorządowych. Niekiedy Dni gromadziły setki uczestników, a w ich przygotowaniu współdziałały różne instytucje kościelne 
i społeczne. Ogłaszały je plakaty i foldery, informowała o nich kościelna i lokalna prasa, ciekawe wystąpienia ukazywały się drukiem w fachowych czasopismach. Biblia była na nowo odkrywana jako księga wiary i jako księga kultury, wspólne dziedzictwo inspirujące do nowych przemyśleń i działań. W niektórych ośrodkach Dni weszły już na stałe do programu i są oczekiwane z rosnącym zainteresowaniem. Zapotrzebowanie na spotkania wokół Biblii mobilizuje organizatorów do szukania wciąż nowych pomysłów, aby jeszcze lepiej trafić do ludzi z przesłaniem biblijnym.

Po tej wymianie zdań ks. Jan Jacek Stefanów, werbista, wygłosił referat pt. „Apostolat biblijny w Ameryce Łacińskiej”. Ks. Stefanów jest obecnie dyrektorem Apostolatu Biblijnego Zgromadzenia Słowa Bożego w Polsce. Wcześniej, po studiach w Hiszpanii i w Rzymie, był odpowiedzialny za apostolat biblijny w Hiszpanii, a potem w Ameryce Łacińskiej. Prelegent podzielił się bogatym doświadczeniem zebranym na kontynencie amerykańskim, gdzie Biblia jest czytana w kontekście aktualnych wydarzeń i inspiruje chrześcijan do konkretnych działań także na polu społecznym i gospodarczym. Jego wystąpienie ukaże się w Kwartalniku Kurii Biskupiej Warszawsko-Praskiej „Bliżej Biblii”, redagowanym przez ks. J. Banaka.

Na koniec uczestnicy spotkania dyskutowali nad Słowem na tegoroczne Dni Biblijne, przygotowanym tym razem przez ks. bpa Michała Jabłońskiego z Kościoła Starokatolickiego Mariawitów. Zatytułowane jest ono „Śpiewajcie Panu...” (Ps 9, 12) i koncentruje się na Księdze Psalmów. Niosą one wciąż aktualne przesłanie o Bogu i człowieku i są wspaniałą skarbnicą modlitw, wykorzystywanych przez Izraelitów, a także przez samego Jezusa i Jego uczniów w ciągu wieków. Warto więc pochylić się nad nimi i uczynić na nowo własnymi. Poniżej przytaczamy to Słowo. Ufamy, że kolejne już Ekumeniczne Dni Biblijne pomogły wielu chrześcijanom odkryć bogactwo psalmów i zasmakować w ich pięknie.

Kraków

KS. STANISEAW WRONKA

\section{„Śpiewajcie Panu..." (Ps 9, 12) \\ Słowo Towarzystwa Biblijnego w Polsce na Ekumeniczne Święto Biblii 2004}

Pismo Święte na różne sposoby przybliża nas do Boga. Daje nam również wzory modlitw i hymnów. Oprócz najwspanialszej Modlitwy Pańskiej, której sam Zbawiciel nauczył apostołów, mamy w Biblii modlitwy wypo- 